\title{
Phytochemical, Antioxidant and Antimicrobial Profiles of Extracts of Daphne alpina (Thymelaeaceae) L Leaf and Twig from Mt Kopaonik (Serbia)
}

\author{
Miroslav Sovrlić ${ }^{\text {, Perica Vasiljević }}{ }^{\text {, Marina Jušković }}{ }^{2}$, Pavle Mašković ${ }^{3}$ and \\ Nedeljko Manojlović ${ }^{1 *}$
}

${ }^{1}$ Faculty of Medical Sciences, University of Kragujevac, 34000, Kragujevac, ${ }^{2}$ Faculty of Sciences and Mathematics, University of Niš, 18000, ${ }^{3}$ Faculty of Agronomy, University of Kragujevac, 32000 Čačak, Serbia

*For correspondence: Email: mtnedeljko@yahoo.com; Tel: +381691137150

\begin{abstract}
Purpose: To investigate the phytochemical composition, as well as antioxidant and antimicrobial activities of the leaf and twig extracts of Daphne alpina L. (Thymelaeaceae).

Methods: The dry chloroform and methanol extracts of the leaf and twigs of Daphne alpina were used for analysis. Total phenolic and flavonoid contents were determined by established procedures. Antioxidant potential was investigated by several methods. The antimicrobial properties of the extracts were obtained by microdilution method. High performance liquid chromatography (HPLC) was employed for the identification of the most abundant metabolites, present in $D$. alpina extracts.

Results: The total phenolics of the extracts ranged from 78.98 to $88.98 \mathrm{mg} \mathrm{GA} / \mathrm{g}$ while total flavonoids were in the range 28.09 to $34.65 \mathrm{mg} \mathrm{GA} / \mathrm{g}$ of fresh weight. HPLC analysis of the extracts showed the presence 4-hydroxybenzoic acid, 7,8-dihydroxycoumarine and 7-hydroxycoumarine. Total antioxidant capacity ranged from $69.71 \mu \mathrm{g} \mathrm{AA} / \mathrm{g}$ for the methanol leaf extract to $73.55 \mu \mathrm{g} \mathrm{AA} \mathrm{g}$ for the chloroform twig extract. All the extracts showed DPPH radical scavenging activity $(21.57-25.45 \mu \mathrm{g} / \mathrm{mL})$, inhibitory activity against lipid peroxidation (26.79 - 35.24 $\mu \mathrm{g} / \mathrm{mL})$, ferrous ion chelating ability $(21.57-45.45$ $\mu \mathrm{g} / \mathrm{ml})$ and hydroxyl radical scavenging activity $(87.98$ - $98.86 \mu \mathrm{g} / \mathrm{mL})$. Minimum inhibitory concentration (MIC) was in the range $15.62-125 \mu \mathrm{g} / \mathrm{mL}$.

Conclusion: The extracts possess moderate antioxidant and antimicrobial activities due probably to the phenolic compounds in the extracts.
\end{abstract}

Keywords: Daphne alpina, Coumarines, 4-Hydroxybenzoic acid, Phenols, Flavonoids, Antimicrobial activity, Antioxidant activity

\footnotetext{
Tropical Journal of Pharmaceutical Research is indexed by Science Citation Index (SciSearch), Scopus, International Pharmaceutical Abstract, Chemical Abstracts, Embase, Index Copernicus, EBSCO, African Index Medicus, JournalSeek, Journal Citation Reports/Science Edition, Directory of Open Access Journals (DOAJ), African Journal Online, Bioline International, Open-J-Gate and Pharmacy Abstracts
}

\section{INTRODUCTION}

Daphne alpina $\mathrm{L}$ is an erect, deciduous small, generally calcicolous shrub of the mountains of southern and central Europe [1]. The relict species Daphne alpina $L$ belongs to the family Thymelaeaceae section Daphnanthes C.A. Mayer, subsection Alpinae [2]. The first compound to be isolated from $D$. alpina was coumarin daphnin (8-hydroxy-7- $\beta$-Dglucosyloxycoumarin) by Vauquelin 1812 [3]. So far, phytochemical analysis has been carried out on the species from the Far East, namely, $D$. odora, $D$. tangutica, D. cannabina, D. genkwa, $D$. acuminata and $D$. papyracea. Of the European species of the genus Daphne, the most numerous data are for the following species: $D$. 
mezereum, D. oleoides, D. gnidium, D. laureola, D. cneorum and partially D. malyana [4].

Analysis of the chemical characteristics of this genus show that plants of the genus Daphne contains many classes of secondary metabolites, some of which are dominated coumarins, flavonoids, lignans, and steroids [5-11]. Daphne species is used for the treatment of skin diseases, malaria, toothache, and also in traditional medicine as a purgative, anticoagulant and diuretic. The bark and fruits of $D$. mezerum in Europe is used for treatment of ulcers, rheumatism and as a purgative. A tincture of $D$. mezereum is used to treat skin diseases such as herpes and dermatitis [7]. About 40 years ago, it was found that mezerein of the species $D$. mezereum has antileukemic activity in the $P$ 388 mouse lymphocytes [12]. Extracts of leaf and twigs of Daphne species showed antibacterial activity $[9,10,13-15]$. However, to date there is still no large number of studies that suggest a wider application of biologically active compounds of this genus in medicine [16]. Continuing our investigation of Daphne species, we relate here the results of the phytochemical analysis (total phenols, flavonoid content, HPLCUV) of leaf and twigs of Daphne alpina.

\section{EXPERIMENTAL}

\section{Plant materials}

The mature leaf and twigs of Daphne alpina $\mathrm{L}$ was collected from Mt Kopaonik (Oštri kršGobelja), Serbia (UTM DN 97) in July 2007. A sample of the plant was deposited in the Herbarium of the Department of Biology and Ecology, Faculty of Sciences and Mathematics, University of Nis, Serbia (HMN 5506).

\section{Preparation of extracts}

Dried and powdered leaf and twigs of $D$. alpina $(2 \times 100 \mathrm{~g})$ were extracted in Soxhlet extractor separately with $500 \mathrm{~mL}$ chloroform and methanol for $6 \mathrm{~h}$. The chloroform and acetone extracts were than filtered and dried in rotary vacuum evaporator at $45{ }^{\circ} \mathrm{C}$ : The dry extracts were used for chemical analysis as well as determination of antimicrobial and antioxidant activities.

\section{HPLC (high performance liquid chromatogra- phy) analysis of $D$. alpina extracts}

The chloroform and acetone extracts and standards (500 $\mu \mathrm{L}$ acetone) subjected to High performance liquid chromatography (HPLC) analysis (Agilant Technologies 1200 Series
HPLC instrument). The column C18 $(25 \mathrm{~cm} \times 4.6$ $\mathrm{mm}$, length of column, $10 \mathrm{~m}$ ) and UV spectrophotometric detector was used. As eluent, methanol-water-phosphoroc acid (85:15: $0.9, \mathrm{v} / \mathrm{v} / \mathrm{v}$ ) was used at a flow-rate of $1 \mathrm{ml} / \mathrm{min}$ and the sample injection volume of $10 \mu \mathrm{l}$. Phosphoric acid was of analytical grade. HPLC grade methanol (E.Merck, Darmstadt, Germany) was used for the HPLC analysis. Deionized water is purchased from Milli-Q academic water purification system (Milford, MA, USA). Standards used in the study (daphnetin, 4hydroxybenzoic acid and umbeliferone) were purified from Sigma -Aldrich (USA).

\section{Microorganisms used in evaluation antimicrobial activity}

The antimicrobial effect of the extracts was determined in vitro toward the standard microbes strains, including bacteria such as Staphylococcus aureus ATCC25923, Escherichia coli ATCC25922, Klebsiella pneumoniae ATCC13883, Proteus mirabilis ATCC14153, Proteus vulgaris ATCC13315, Bacillus subtilis ATCC6633 and fungi Aspergillus niger ATCC16404 and Candida albicans ATCC10231). The bacteria were cultured on agar for 7 days at room temperature of $25^{\circ} \mathrm{C}$ under alternating light and dark conditions. They were recultured on a new agar substrate for another 5 days. Fungal strains were grown on potato-glucose agar at room condition involving temperature of $20^{\circ} \mathrm{C}$, intermittently light and dark condition during for 7 days. Subculturing of the fungi is carried out for another 7 days using the new potato-glucose medium. The cultivation procedure of tested microorganisms was repeated four times to obtain pure culture. The microorganisms that were used were confirmed to Department of Microbiology, Institute Torlak, Belgrade, Serbia.

\section{Measurement of minimum inhibitory concen- tration (MIC) of D. alpina extracts}

MIC of the crude extracts was performed by microdilution method using the 96 multi-well microtiter plates [17]. All testing of bacterial and fungal cultures were performed in Mueller-Hinton broth and Sabouraud dextrose broth, respectively. In the first row of the plate was applied a volume of $100 \mu \mathrm{L}$ methanol stock solutions of $D$. alpina extracts $(200 \mu \mathrm{g} / \mathrm{mL})$ and a solution of cirsimarin (2 mg/mL) in $10 \%$ DMSO. In other wells was added $50 \mu \mathrm{L}$ of Mueller Hinton or Sabouraud dextrose broth with addition a Tween 80 to the total concentration of $0.5 \%(\mathrm{v} / \mathrm{v})$ for analysis of extracts. From the first row test wells was transferred volume of $50 \mu \mathrm{L}$ into the second row wells. Thereafter, from the second to 
the twelfth well a volume of $50 \mu \mathrm{L}$ of scalar dilution was transferred. Then, to each well was added $10 \mu \mathrm{L}$ of indicator solution (prepared by dissolving resazurin in sterile distilled water) and $30 \mu \mathrm{L}$ of nutrient broth. Finally, to each well was added $10 \mu \mathrm{L}$ of bacterial suspension $\left(10^{6}\right.$ CFU $/ \mathrm{mL})$ and yeast spore suspension $\left(3 \times 10^{4}\right.$ $\mathrm{CFU} / \mathrm{mL}$ ). Amracin (tetracycline hydrochloride) and ketoconazole were used as positive control for the test bacteria and yeast, respectively. The plates were wrapped loosely with cling film to ensure that bacteria did not become dehydrated. The plates were prepared in triplicate and incubated at $37^{\circ} \mathrm{C}$ for $24 \mathrm{~h}$ for the bacteria and at $28{ }^{\circ} \mathrm{C}$ for $48 \mathrm{~h}$ for the yeast. Mean MIC $(\mathrm{n}=3)$ for the test extracts and standard drug were taken.

\section{Determination of the total phenolic and flavonoid contents}

The total phenolic content of the chloroform and acetone extracts were determined spectrophotometrically using the Folin-Ciocalteu method [18]. The absorbance was read at 765 $\mathrm{nm}$ using spectrophotometer. Total phenolic content was expressed as $\mathrm{mg}$ gallic acid equivalents per gram of crude extract (mg GA/g extract). Total flavonoid content of the tested extracts was determined following a previously reported method [19]. Total flavonoid content was expressed as $\mathrm{mg}$ rutin equivalents per gram of extract (mg RU/g extract).

\section{Phytochemical screening of the tested extracts}

Phytochemical screening of the tested extracts for the presence of coumarins and flavonoids, was carried out.

Test for coumarins: $300 \mathrm{mg}$ of the extracts was covered with filter paper moistened with $1 \mathrm{M}$ $\mathrm{NaOH}$ in a small test tube. The test tube was placed for few minutes in a boiling water bath and after removing the filter paper it was examined under UV light. Presence of coumarines was confirmed by yellow florescence. All tested extracts (CHLT, CHLL, METT and METL) gave positive test for coumarines.

Test for flavonoids: $50 \mathrm{mg}$ of the extracts was suspended in $100 \mathrm{ml}$ of distilled water to get the filtrate. $5 \mathrm{ml}$ of dilute ammonia solution was added to $10 \mathrm{ml}$ of filtrate followed by few drops of concentrated $\mathrm{H}_{2} \mathrm{SO}_{4}$. Yellow colouration indicated the presence of flavonoids. All tested extracts (CHLT, CHLL, METT and METL) gave positive test for flavonoids.

\section{Determination of total antioxidant capacity}

A spectrophotometric method, based on the reduction of $\mathrm{Mo}(\mathrm{VI})$ to $\mathrm{Mo}(\mathrm{V})$, applied to assessment the total antioxidant activity of $D$. alpina extracts [20]. The solution of tested extracts in methanol was cooled to room temperature and absorbance was measured at $695 \mathrm{~nm}$ against the blank. As a blank test was used methanol in the absence of extract. Ascorbic acid (AA) was used as the positive control and total antioxidant capacity was expressed as ascorbic acid equivalents (mg AA/g crude extract).

\section{Determination of antioxidant activity by DPPH assay}

Diphenyl - picryl-hydrazyl assay described by Takao with modifications from Kumarasamy was used to estimate DPPH radical scavenging ability of $D$. alpina extracts $[21,22]$. Stock solution of the reference antioxidants was prepared by dissolving the substance in methanol (in the same concentrations). For reference standards, gallic acid (GA), butylated hydroxytoluene (BHT) and ascorbic acid (AA) were used while methanol was used as blank. The percentage inhibition of the DPPH radical was calculated as in Eq 1.

Inhibition $(\%)=\{$ Ac - As $) / A c\} 100$

where Ac and As are the absorbance of control and test samples, respectively

The concentration of extract that reduces absorbance of DPPH by $50 \%$ defined as the $\mathrm{IC}_{50}$ value. $\quad \mathrm{IC}_{50}$ was calculated graphically from sigmoidal dose-response curve and expressed in $\mu \mathrm{g} / \mathrm{mL}$.

\section{Peroxy radical scavenging activity}

The thiocyanate method used to determine antioxidant activity of tested extracts [20]. As reference compounds were used gallic acid (GA), ascorbic acid (AA), butylated hydroxytoluene (BHT) and a-tocopherol. The control sample, which contained the same amount of solvent added to the linoleic acid emulsion in the test sample and reference compound, was used to eliminate the solvent effect. The percent of inhibition of linoleic acid peroxidation was calculated using the Eq. 1. 


\section{Measurement of ferrous ion chelating effect}

The ferrous ion chelating ability was determined by measuring the decrease in absorbance at 562 $\mathrm{nm}$ as a result of the direct reduction of $\mathrm{Fe}^{3+}$ to $\mathrm{Fe}^{2+}[23,24]$. Increased absorbance of the reaction mixture indicates grater reduction capability. The percentage ferrous ion chelating ability of the extracts was calculated relative to the control and express by the following Eq.1.

\section{Measurement of hydroxyl radical scavenging activity}

Hydroxil radical scavenging activity of the chloroform and methanol extracts was determined following a previously reported method [25]. The absorbance of the solution at $532 \mathrm{~nm}$ was obtained to determine extent of oxidation of 2-deoxyribose. The percentage inhibition values were calculated from the absorbance of the control (Ac) and of the sample (As), where the controls contained all the reaction reagents except the extract or positive control substance. The presented values are mean values of three measurements.

\section{Statistical analysis}

All analyses were carried out in triplicates and the data presented as mean \pm standard deviation (SD). $I_{50}$ values were obtained by nonlinear regression analysis from the sigmoidal doseresponse inhibition curve. Statistical differences were analyzed using one-way ANOVA, followed by Tukey's HSD post hoc comparison test; $p<$ 0.05 was regarded as significant. The statistical software, SYSTAT 12 (Systat Software, Inc. 2007), was used for all computations.

\section{RESULTS}

\section{Total phenolic and total flavonoid contents}

Total phenolic and total flavonoid contents of the chloroform and methanol extracts are shown in Table 1. The total phenolic contents varied over the range $78.98-88.98 \mathrm{mgGA} / \mathrm{g}$, among the tested extracts. The highest total phenolic contents (88.98 $\mathrm{mgGA} / \mathrm{g}$ extract) was observed for METT. The otal flavonoid content ranged over 28.09-34.65 mg RU/g extract. The highest total flavonoid content was recorded for CHLT, while the lowest was for CHLL. The content of total phenolic and flavonoids of the chloroform and methanol extracts of $D$. alpina was statistical different, while recorded differences were not significant between CHLT/CHLL and METT/METL.

\section{Chromatographic data for $D$. alpina extracts}

The HPLC chromatograms for standards (daphnetin, 4-hydroxybenzoic acid and umbeliferone) and extracts of $D$. alpina are shown in Figures 1 - 3.

Table 1: Total phenolic and total flavonoid content and total antioxidant capacity of the chloroform and methanol extracts of $D$. alpina

\begin{tabular}{|c|c|c|c|}
\hline D. alpina extract & $\begin{array}{l}\text { Total phenolic } \\
\text { content } \\
(\mathrm{mg} \mathrm{GA} / \mathrm{g})\end{array}$ & $\begin{array}{l}\text { Total } \\
\text { flavonoids } \\
\text { (mg RU/g) }\end{array}$ & $\begin{array}{l}\text { Total antioxidant capacity } \\
(\mu \mathrm{g} A \mathrm{~A} / \mathrm{g})\end{array}$ \\
\hline $\mathrm{CHLT}$ & $80.56 \pm 0.35$ & $34.65 \pm 0.89$ & $73.55 \pm 1.02$ \\
\hline CHLL & $78.98 \pm 0.67$ & $28.09 \pm 0.85$ & $70.01 \pm 0.54$ \\
\hline METT & $88.98 \pm 1.05$ & $31.45 \pm 0.15$ & $71.11 \pm 1.12$ \\
\hline \multirow[t]{2}{*}{ METL } & $85.88 \pm 0.97$ & $32.65 \pm 0.89$ & $69.71 \pm 0.54$ \\
\hline & $P$-value & & \\
\hline ANOVA & * & * & * \\
\hline \multicolumn{4}{|l|}{ Tukey's HSD test } \\
\hline $\mathrm{CHLT/CHLL}$ & n.s. & * & * \\
\hline CHLT/METT & * & * & * \\
\hline CHLT/METL & * & * & n.s. \\
\hline CHLL/METT & * & * & n.s. \\
\hline CHLL/METL & * & * & n.s. \\
\hline METT/METL & * & n.s. & n.s. \\
\hline
\end{tabular}

Values are the mean $\pm S D$. Data were analysed by analyses of variance (ANOVA) procedure and Tukey`s HSD post hoc comparison test ( ${ }^{*} p<0.05$; n.s. not significant). CHLT-chloroform extract of twigs; CHLL- chloroform extract of leafs; METT-methanol extract of twigs; METL-methanol extract of leaf 

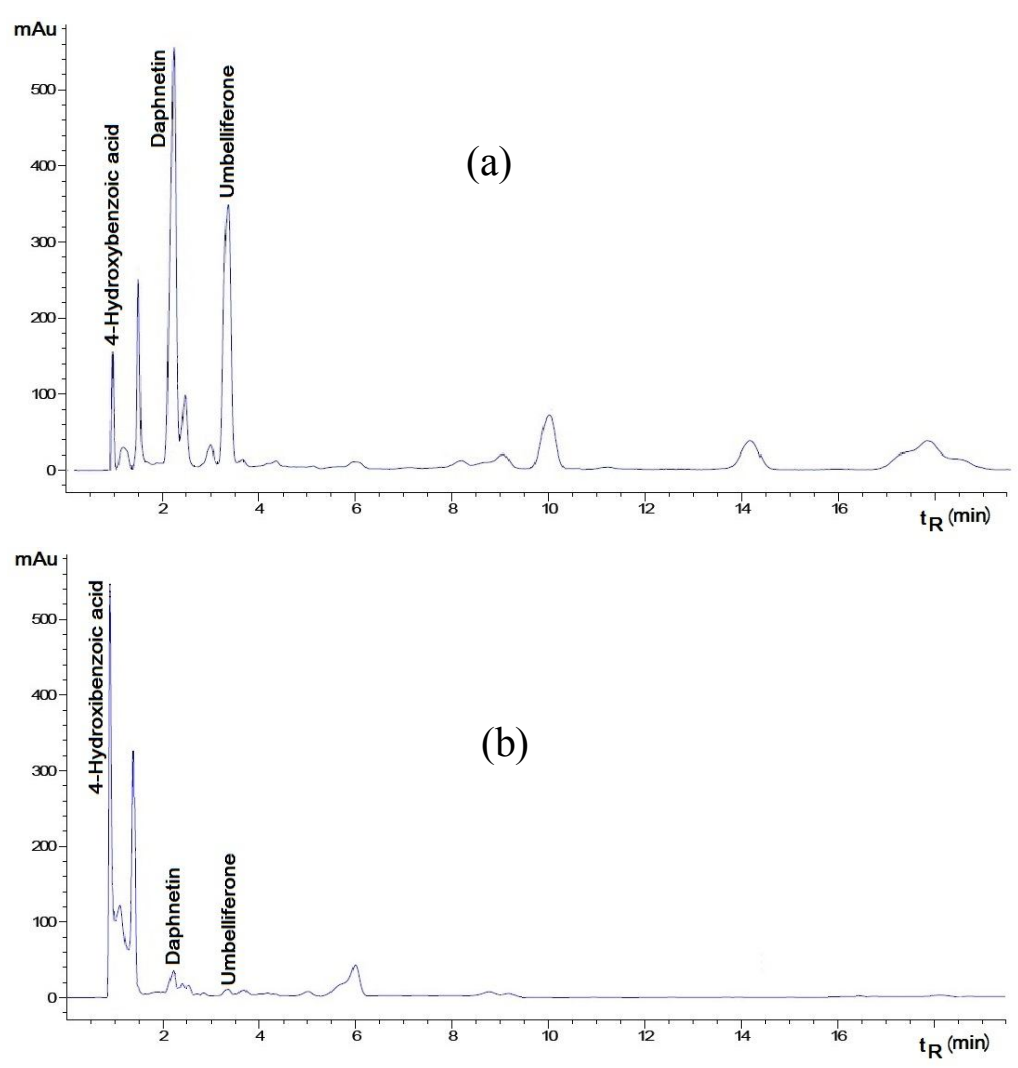

Figure 1: HPLC chromatogram of the $D$. alpina twigs at $325 \mathrm{~nm}$. Note: a) chloroform extract; b) methanol extract
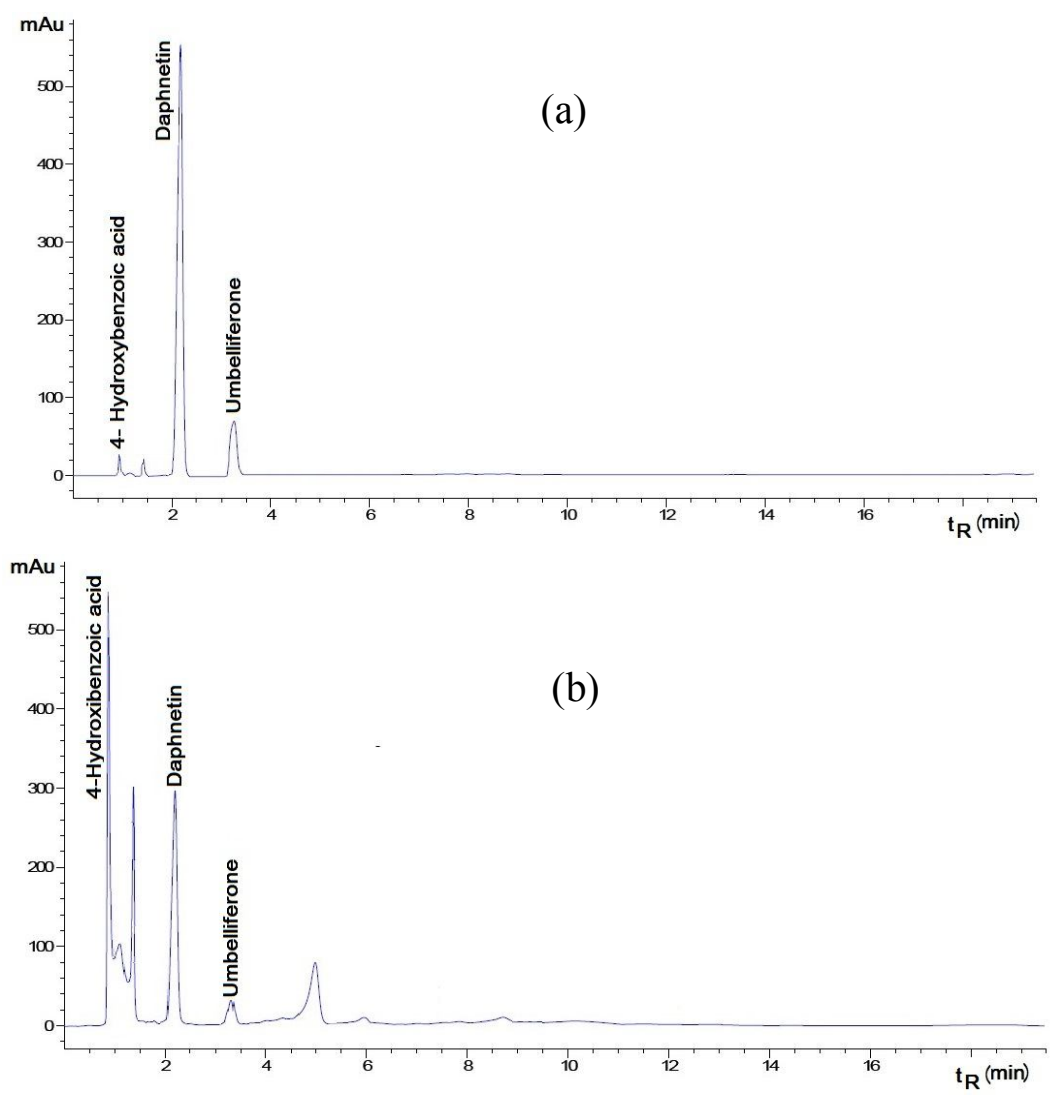

Figure 2: HPLC chromatogram of $D$. alpina leaf at $325 \mathrm{~nm}$ a) chloroform extract; b) methanol extract 

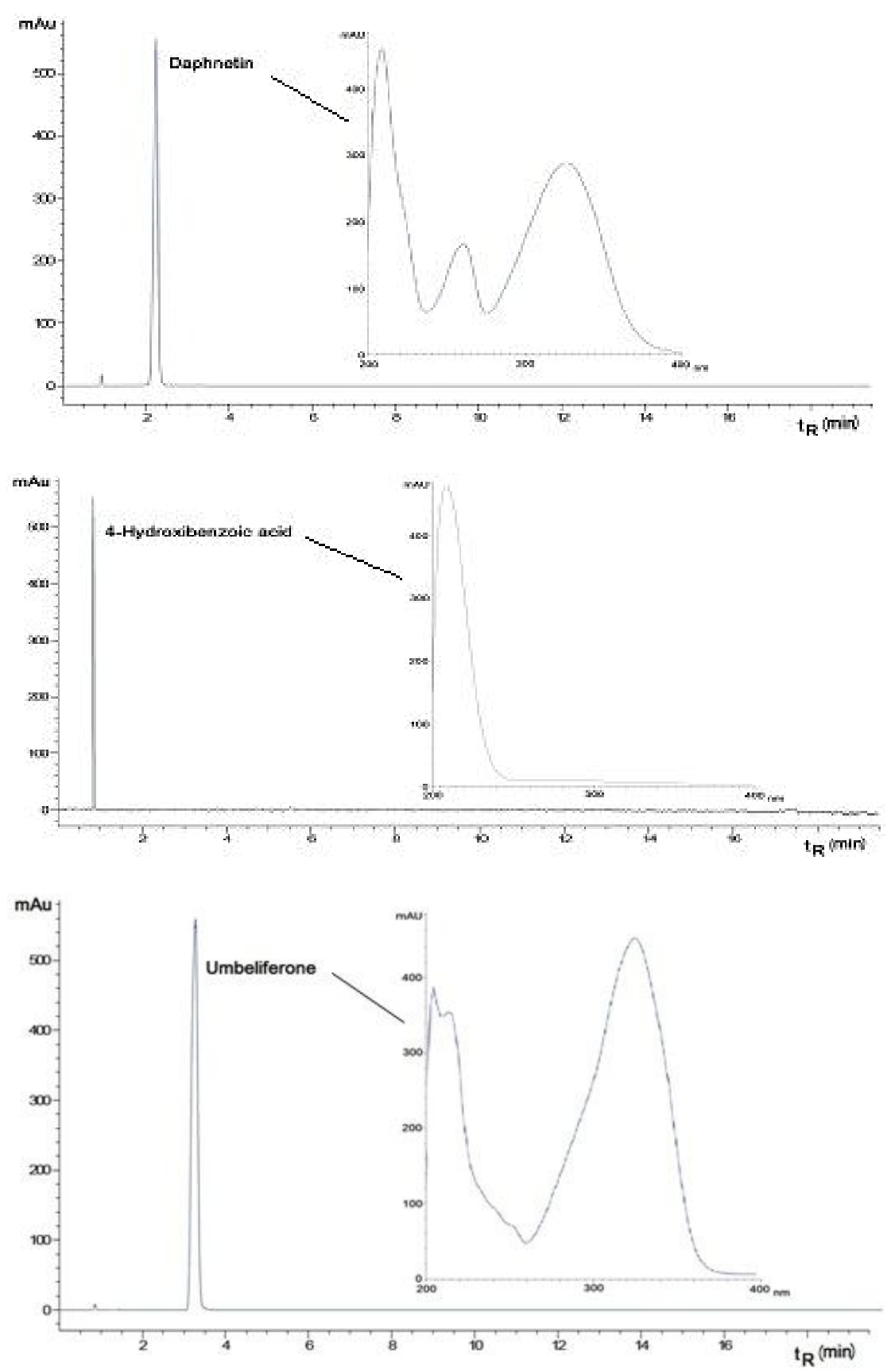

Figure 3: HPLC chromatograms and UV spectra of standards<smiles>O=c1ccc2ccc(O)c(O)c2o1</smiles>

Daphnetin<smiles>O=C(O)c1ccc(O)cc1</smiles>

4-Hydroxybenzoic acid<smiles>O=c1ccc2ccc(O)cc2o1</smiles>

Umbelliferone

Figure 4: The structures of the identified compounds from HPLC chromatograms of $D$. alpina extracts 
As it can be seen in the both the chromatograms and UV spectra, there were present of 4hydroxybenzoic acid ( $t_{R}=0.96 \pm 0.10 \mathrm{~min}$ ), and two hydroxylated derivative of coumarin, 7, 8 dihydroxycoumarine (daphnetin, $t_{R}=2.25 \pm 0.10$ min) and 7-hydroxycoumarine (umbelliferone, $t_{R}$ $=2.63 \pm 0.10 \mathrm{~min}$ ), as the most represented compounds in the tested extracts. Identification of the above-mentioned substances was achieved on the basic of their retention times $\left(t_{R}\right)$ which was compared with the corresponding values for the standard substances. The UV absorbance maxima (from 200-400 nm) also corresponded with the values of standards. Their structures were shown in Fig 4.

Daphnetin has the most intense peaks in the HPLC chromatogram of the chloroform extracts of $D$. alpina twigs and leaf. This compound belongs to the coumarines and has three characteristic absorption maxima at 204, 261 and $325 \mathrm{~nm}$.

\section{Total antioxidant capacity}

The total antioxidant capacity (TAC) was determined using phosphomolybdenum method. It was ranged from $69.71 \pm 0.54 \mu \mathrm{g} \mathrm{AA} / \mathrm{g}$ for the methanol extract of leaf to $73.55 \pm 1.02 \mu \mathrm{g} \mathrm{AA} / \mathrm{g}$ for the chloroform extract of twigs (Table 1). ANOVA showed significance in the total antioxidant capacity of the extract. Tukey's HSD post hoc comparison test indicates a statistically significant difference in the total antioxidant capacity of the CHLT/CHLL and CHLT/METT. The methanol extract of twigs had the highest activity $\left(\mathrm{IC}_{50}=21.57 \pm 1.03 \mu \mathrm{g} / \mathrm{mL}\right)$, followed the methanol extract of leaf $\left(\mathrm{IC}_{50}=23.15 \pm 1.05\right.$ $\mu \mathrm{g} / \mathrm{mL})$, the chloroform extracts of twigs $\left(\mathrm{IC}_{50}=\right.$ $25.45 \pm 1.05 \mu \mathrm{g} / \mathrm{mL}$ ) and the chloroform extract of leaf $\left(\mathrm{IC}_{50}=25.45 \pm 0.89 \mu \mathrm{g} / \mathrm{mL}\right)$.

\section{DPPH scavenging}

DPPH scavenging activity ( $\mathrm{IC}_{50}$ values) in various extract of $D$. alpina leaf and twigs are shown in Table 2. These values for the all extracts were higher than $20 \mu \mathrm{g} / \mathrm{mL}$. The methanol extract of twigs had the highest activity $\left(\mathrm{IC}_{50}=21.57 \pm 1.03\right.$ $\mu \mathrm{g} / \mathrm{mL})$, followed the methanol extract of leaf $\left(\mathrm{IC}_{50}=23.15 \pm 1.05 \mu \mathrm{g} / \mathrm{mL}\right)$, the chloroform extracts of twigs and leaf $\left(\mathrm{IC}_{50}=25.45 \pm 1.05\right.$ $\mu \mathrm{g} / \mathrm{mL}$ and $\left.\mathrm{IC}_{50}=25.45 \pm 0.89 \mu \mathrm{g} / \mathrm{mL}\right) . I_{50}$ value determined for chloroform extracts of twigs and leaf were significantly different from methanol extract of leaf. However, the scavenging activities of all extracts were less than those of standard compounds-BHT. Table 2 shows the $\mathrm{IC}_{50}$ values (mean $\pm \mathrm{SD}$ ) of chloroform and methanol extracts of $D$. alpina compared with BHT. Data were analyzed by analyses of variance (ANOVA) procedure followed by Tukey`s HSD post hoc comparison test.

\section{Anti-lipid peroxidation}

The results of inhibitory activity against lipid peroxidation for the tested extracts of $D$. alpina are shown in Table 2. The methanol extract of leaf had highest lipid peroxidation inhibition $\left(\mathrm{IC}_{50}\right.$ $=26.79 \pm 0.34 \mu \mathrm{g} / \mathrm{mL})$, followed the chloroform extract of leaf $\left(\mathrm{IC}_{50}=27.87 \pm 1.03 \mu \mathrm{g} / \mathrm{mL}\right)$, the chloroform extract of twigs $\left(\mathrm{IC}_{50}=34.23 \pm 0.89\right.$ $\mu \mathrm{g} / \mathrm{mL})$ and the methanol extract of twigs $\left(\mathrm{IC}_{50}=\right.$ $35.24 \pm 0.55 \mu \mathrm{g} / \mathrm{mL})$. The methanol and chloroform extracts of leaf showed greater inhibition of lipid peroxidation then twigs extracts. The $I_{50}$ values obtained for the tested extracts were significantly higher than the $I_{50}$ value obtained for BHT.

\section{Metal-chelating ability}

Based on the obtained results in Table 2, it can be concluded that the constituents of $D$. alpina extracts has the ability to create complex with ferrous ion. As compared for $\mathrm{IC}_{50}$ values, metal chelating ability of methanol extracts (21.57 \pm $1.03 \mu \mathrm{g} / \mathrm{mL}$ for twigs and $23.15 \pm 1.05 \mu \mathrm{g} / \mathrm{mL}$ for leaf), were more effective than that of the chloroform extract of twigs $(45.45 \pm 1.15 \mu \mathrm{g} / \mathrm{mL})$ and leaf $(44.65 \pm 0.99 \mu \mathrm{g} / \mathrm{mL})$. Statistical analysis of the potential of the extracts for the ability to metal chelating indicate statistical significance between the $I_{50}$ values of the methanol and chloroform extracts of $D$. alpina (Table 2).

\section{Hydroxyl radical scavenging activity}

The results of hydroxyl radical scavenging activity are shown in Table 2. For the tested extracts, the chloroform extract of twigs had the highest $\mathrm{IC}_{50}$ value $(98.86 \pm 0.94 \mu \mathrm{g} / \mathrm{mL})$, followed by the methanol extract of twigs $(91.55 \pm 1.05$ $\mu \mathrm{g} / \mathrm{mL})$, the methanol extract of leaf (87.98 \pm $1.07 \mu \mathrm{g} / \mathrm{mL}$ ) and the chloroform extract of leaf $(80.56 \pm 1.05 \mu \mathrm{g} / \mathrm{mL})$. The potential of all extracts to scavenge hydroxyl radical were significantly different from the $I_{50}$ values obtained for standard compounds.

\section{Correlations}

Trop J Pharm Res, July 2015; 14(7): 1245 
The results of correlation of total phenolic and

Table 2: Free radical scavenging activity of the chloroform and methanol extracts of $D$. alpina

\begin{tabular}{|c|c|c|c|c|}
\hline $\begin{array}{l}\text { Extracts of } \\
\text { D.alpina }\end{array}$ & DPPH & $\begin{array}{l}\text { Inhibitory activity } \\
\text { against lipid } \\
\text { peroxidation }\end{array}$ & $\begin{array}{l}\text { Ferrous ion } \\
\text { chelating ability }\end{array}$ & $\begin{array}{l}\text { Hydroxyl radical } \\
\text { scavenging activity }\end{array}$ \\
\hline & $\mathrm{IC}_{50}(\mu \mathrm{g} / \mathrm{mL})$ & $\begin{array}{l}\mathrm{IC}_{50} \\
(\mu \mathrm{g} / \mathrm{mL})\end{array}$ & $\begin{array}{l}C_{50} \\
(\mu \mathrm{g} / \mathrm{mL})\end{array}$ & $\begin{array}{l}C_{50} \\
(\mu g / m L)\end{array}$ \\
\hline$\overline{\mathrm{CHLT}}$ & $25.45 \pm 1.05$ & $34.23 \pm 0.89$ & $45.45 \pm 1.15$ & $98.86 \pm 0.94$ \\
\hline CHLL & $25.45 \pm 0.89$ & $27.87 \pm 1.03$ & $44.65 \pm 0.99$ & $80.56 \pm 1.05$ \\
\hline METT & $21.57 \pm 1.03$ & $35.24 \pm 0.55$ & $21.57 \pm 1.03$ & $91.55 \pm 1.05$ \\
\hline METL & $23.15 \pm 1.05$ & $26.79 \pm 0.34$ & $23.15 \pm 1.05$ & $87.98 \pm 1.07$ \\
\hline \multirow[t]{2}{*}{$\mathrm{BHT}$} & $15.61 \pm 1.26$ & $1.00 \pm 0.23$ & - & $33.92 \pm 0.79$ \\
\hline & \multicolumn{4}{|l|}{$P$-value } \\
\hline ANOVA & * & * & * & * \\
\hline \multicolumn{5}{|l|}{ Tukey`s HSD test } \\
\hline $\mathrm{CHLT/CHLL}$ & n.s. & * & n.s. & * \\
\hline CHLT/METS & $*$ & n.s. & * & * \\
\hline CHLT/METL & n.s. & * & * & * \\
\hline $\mathrm{CHLT/BHT}$ & * & * & - & * \\
\hline CHLL/METT & * & * & * & * \\
\hline CHLL/METL & n.s. & n.s. & * & * \\
\hline $\mathrm{CHLL/BHT}$ & * & * & - & * \\
\hline METT/METL & n.s. & * & n.s & * \\
\hline METT/BHT & * & * & - & * \\
\hline METL/BHT & * & * & - & * \\
\hline
\end{tabular}

${ }^{*} p<0.05 ;$ n.s. - not significant

flavonoids contents with antioxidant assays of $D$. alpina are shown in Table 3. A significant correlation of $\mathrm{IC}_{50}$ values of metal chelating ability and DPPH was established with total phenolic contents, while a significant correlation exists between the hydroxyl radical scavenging activity and flavonoids content. A no significant correlation was found between $I_{50}$ values of anti-lipid peroxidation assay, and hydroxyl radical and total phenolic respectively anti-lipid peroxidation assay, DPPH and metal chelating ability and flavonoid contents.

\section{Antimicrobial activity}

The results reveal antimicrobial activity of the chloroform and methanol extracts of $D$. alpina within the concentration range from 15.62 to 125 $\mu \mathrm{g} / \mathrm{mL}$. The highest susceptibility to the chloroform extract of $D$. alpina twigs among the bacteria tested was exhibited by $B$. subtilis ATCC6633 (15.62 $\mu \mathrm{g} / \mathrm{mL})$ followed by strains of $K$. pneumoniae ATCC13883 and E. coli ATCC25922 (31.25 $\mu \mathrm{g} / \mathrm{mL})$ and $P$. vulgaris ATCC13315 and $P$. mirabilis ATCC14153 (62.5 $\mu \mathrm{g} / \mathrm{mL})$.

The chloroform and methanol extracts showed comparatively efficient MIC value $31.25 \mu \mathrm{g} / \mathrm{mL}$ against $S$. aureus, $K$. pneumoniae, $E$. coli, $P$. vulgaris, $C$. albicans and $A$. niger (Table 4 ). The highest susceptibility to the methanol extract of
$D$. alpina leaf among the bacteria tested was exhibited by $P$. vulgaris ATCC13315 (MIC = $15.62 \mu \mathrm{g} / \mathrm{ml}$ ). On the other hand, antifungal activity of the chloroform and methanol extracts of $D$. alpina was within the concentration range from 31.25 to $125 \mu \mathrm{g} / \mathrm{mL}$.

Comparison of antimicrobial activity shows that chloroform extracts exhibited higher activity against selected strains of microorganisms then the methanol extracts, exception is the effect on $P$. mirabilis where MIC value is the same for all types of extracts.

\section{DISCUSSION}

A preliminary analytical investigation of the chloroform and methanol extracts obtained from the leaf and the stems of Daphne alpina was performed to determine total phenolic and flavonoid contents. The total phenolic contents of leaf and twigs extracts of $D$. alpina as gallic acid equivalents were found to be highest in the methanol extract of twigs (METT) followed by the chloroform extract of leaf (METL), the chloroform extract of twigs (CHLT) and the chloroform extract of leaf (CHLL).

The results also showed that the highest total flavonoid content were found in the chloroform extract of twigs and lowest in the chloroform extract of leaf. Our previous study on Daphne 
blagayana extracts showed higher content of flavonoids and phenols in twigs than leaf extracts Table 3: Correlation of the total phenolic and flavonoids content with antioxidant assays of the $D$. alpina extracts

\begin{tabular}{lll}
\hline & Correlation $\mathbf{R}^{2}$ & \\
\hline Assays & Total phenolic & Flavonoids \\
\hline $\mathrm{IC}_{50}$ of DPPH radical scavenging potential & 0.774 & 0.160 \\
$\mathrm{I} \mathrm{C}_{50}$ of inhibition of lipid peroxidation & 0.296 & 0.427 \\
$\mathrm{I} \mathrm{C}_{50}$ of ferrous ion chelating ability & 0.941 & 0.103 \\
$\mathrm{IC}$ of hydroxyl radical scavenging potential & 0.192 & 0.890 \\
\hline
\end{tabular}

Table 4: Minimum Inhibitory Concentrations $(\mu \mathrm{g} / \mathrm{ml})$ of chloroform and methanol extracts of $D$. alpina leaf and twigs

\begin{tabular}{lclllll}
\hline & MIC $(\boldsymbol{\mu g} / \mathbf{m L})$ & & & & \\
Microorganism & $\boldsymbol{C H L T}$ & $\boldsymbol{C H L L}$ & $\boldsymbol{M E T T}$ & $\boldsymbol{M E T L}$ & $\boldsymbol{T E T}$ & KET \\
\hline S. aureus ATCC25923 & 62.5 & 31.25 & 62.5 & 31.25 & 0.98 & $\mathrm{nt}$ \\
K. pneumoniae ATCC13883 & 31.25 & 31.25 & 62.5 & 125 & 0.49 & $\mathrm{nt}$ \\
E. coli ATCC25922 & 31.25 & 31.25 & 62.5 & 31.25 & 0.98 & $\mathrm{nt}$ \\
P. vulgaris ATCC13315 & 62.5 & 31.25 & 62.5 & 15.62 & 1.95 & $\mathrm{nt}$ \\
P. mirabilis ATCC14153 & 62.5 & 62.5 & 62.5 & 62.5 & 1.95 & $\mathrm{nt}$ \\
B. subtilis ATCC6633 & 15.62 & 15.62 & 62.5 & 125 & 0.24 & $\mathrm{nt}$ \\
C. albicans ATCC10231 & 62.5 & 31.25 & 62.5 & 125 & 0.98 & $\mathrm{nt}$ \\
A. niger ATCC 16404 & 62.5 & 31.25 & 62.5 & 125 & $\mathrm{Nt}$ & 0.98 \\
\hline
\end{tabular}

[29]. The results of the HPLC analysis suggested that all $D$. alpina extracts containing 4 - hydroxybenzoic acid, 7 - hydroxy coumarine and 7,8 - dihydroxy coumarine, as the major compounds Daphnetin has the most intense peaks in the HPLC chromatogram of the chloroform extracts of twigs and leaf. This compound belongs to the coumarines and has three characteristic absorption maxima at 204 , 261 and $325 \mathrm{~nm}$.

Results of the antioxidant and antimicrobial potential of extracts of $D$. alpina are similar to the results of other studied Daphne species from Serbia (D. cneorum, D. blagayana) [11,29,31] except endemic $D$. malyana [10]. These results can be explained by a similar chemical composition of the examined species Daphne dominated flavonoids and coumarins (daphnetin) which are the main carriers of biological activity in this genus.

Daphnetin has been found in several species of the genus Daphne and has been reported to possess different biological activity including antimicrobial, antioxidant, antimalarial, anticoagulation and immunomodulating activities $[8,9,15,26,28]$.

The study for antimicrobial activity of Daphne gnidium extracts showed that the daphnetin is one of most active compounds [30]. His presence in the $D$. alpina extracts indicates that he is largely responsible for the manifested antimicrobial activity. However, the presence of other metabolites can contribute to the manifest activities.

\section{CONCLUSION}

D. alpina leaf and twig have high phenolic and flavonoid contents which contribute to the antioxidant and antimicrobial activities of this plant. HPLC-UV analysis of the leaves and twigs showed that their chloroform and methanol extracts contain 4-hydroxybenzoic acid, 7hydroxycoumarine (umbeliferone) and 7,8dihydroxycoumarine (daphnetin) as the major compounds. The extracts possess moderate antioxidant and antimicrobial activities and the phenolic compounds are believed to be responsible for these activities.

\section{ACKNOWLEDGEMENT}

This work was financially supported by Ministry of Education and Science of the Republic of Serbia (Grant no. 172015) and Junior Project grant (no. 201/05) from Faculty of Medical Sciences, University of Kragujevac, Serbia.

\section{REFERENCES}

1. Tutin TG, Heywood VH, Burges NA, Moore DM, Valentine $D H$, Walters SM, Webb DA. Flora Europaea Vol 2. Roseaceae to Umbelliferae. Cambridge University Press; 1978; pp 256-258.

2. Keissler K. Die Arten der Gattung, Daphne aus der Section Daphnanthes. Volume 25. Botanische Jahrbucher; 1898; pp 29-124.

Trop J Pharm Res, July 2015; 14(7): 1247 
3. Waksmundzka-Hajnos M, Sherma J. High performance liquid chromatography in phytochemical analysis. CRC Press; 2011; $p 749$.

4. Juan C, Liu X, Shi YP.Determination of daphnetin in Daphne tangutica and its medicinal preparation by liquid chromatography. Anal Chimica Acta 2004; 523(1): 29-33.

5. Cabrera E, Garcia-Granados A. Phytochemistry of Thymelaeaceae. III. Flavonoids and coumarins from Daphne gnidium L. leaves. An Quim. 1982; 77:31-34.

6. Kreher $B$, Wagner $H$, Neszmélyi A. Triumbellin, a tricoumarin rhamnopyranoside from Daphne mezereum. Phytochemistry 1990; 29(11): 3633-3637.

7. Riaz, Muhammad. Phytochemical investigations on Daphne oleoides (PhD Thesis). University of Karachi; 2001.

8. Deiana M, Rosa A, Casu V, Cottiglia F, Bonsignore L, Dessi MA. Chemical composition and antioxidant activity of extracts from Daphne gnidium L. J Am Oil Chem Soc 2003; 80(1): 65-70.

9. Alonso C, Pérez R, Nieto PM, Delgado J. Gender dimorphism and altitudinal variation of secondary compounds in leaves of the gynodioecious shrub Daphne laureola. J Chem Ecol 2005; 31(1): 139-150.

10. Jušković $M$, Vasiljević $P$, Manojlović N, Mihailov-Krstev T., Stevanović B. Phytochemical and antimicrobial screening of leaves and stems of Balkan endemic species Daphne malyana Blečić. Biotechnol Biotec EQ 2012; 26(3): 3010-3015.

11. Manojlović N, Mašković $P$, Vasiljević $P$, Jelić $R$, Jusković M, Sovrlić M, Mandić L, Radojković M. HPLC Analysis, antimicrobial and antioxidant activities of Daphne cneorum L. Hem Ind 2012; 66(5): 709-716.

12. Kupchan SM, Baxter RL. Mezerein: antileukemic principle isolated from Daphne mezereum L. Science 1975; 187(4177): 652-653.

13. Collee JG. Applied Medical Microbiology. London: Blackwell Science Publications; 1976; $p 93$.

14. Sleigh TD, Timburg MC. Notes on Medicial Bacteriology. London: Churchill Livingstone; 1981; p 43.

15. Cottiglia F, Loy G, Garau D, Floris C, Caus M, Pompei R, Bonsignore L. Antimicrobial evaluation of coumarins and flavonoids from the stems of Daphne gnidium $L$. Phytomedicine 2001; 8(4): 302-305.

16. Brickell CD, Mathew B. Daphne: The Genus in the Wild and in Cultivation. Woking, Alpine Garden Society; 1976.

17. Satyajit $D$, Sarker $L N$ and Kumarasamy Y. Microtitre plate based antibacterial assay incorporateing resazurin as indicator of cell growth, and its application in the in vitro antibacterial screening of phytochemicals. Methods 2007; 42(4): 321-324.

18. Singleton V, Orthofer R, Lamuela-Raventos RM. Analysis of total phenols and other oxidation substrates and antioxidants by means of Folin-Ciocalteu reagent. Methods Enzymol 1999; 299C: 152-175.
19. Brighente IMC, Dias $M$, Verdi LG, Pizzolatti MG. Antioxidant activity and total phenolic content of some Brazilian species. Pharm Biol 2007; 45(2): 156-161.

20. Prieto $P$, Pineda $M$, Aguilar $M$. Spectrophotometric quantitation of antioxidant capacity through the formation of a phosphomolybdenum complex: specific application to the determination of vitamin $E$. Anal Biochem 1999; 269(2): 337-341.

21. Takao T, Watanabe N, Yagi I, Sakata K. A simple screening method for antioxidants and isolation of several antioxidants produced by marine bacteria from fish and shellish. Biosci Biotechnol Biochem 1994; 58(10): 1780-1783.

22. Kumarasamy $Y$, Byres $M$, Cox PJ, Jaspars $M$, Nahar L, Sarker SD. Screening seeds of some Scottish plants for free radical scavenging activity. Phytother Res 2007; 21(7): 615-621.

23. Carter $P$. Spectrophotometric determination of serum iron at the submicrogram level with a new reagent (ferrozine). Anal Biochem 1971; 40(2): 450-458.

24. Lim YY, Lim TT, Tee JJ. Antioxidant properties of guava fruit: comparison with some local fruits. Sunw Acad J 2006; 3: 9-20.

25. Hinneburg I, Dorman HJD, Hiltunen R. Antioxidant activities of extracts from selected culinary herbs and spices. Food Chem 2006; 97(1): 122-129.

26. Hong YL, Pan HZ, Scott MD, Meshnick SR. Activated oxygen generation by a primaquine metabolite: Inhibition by antioxidants derived from Chinese herbal remedies. Free Radic Biol Med 1992; 12(3): 213218.

27. Liu SX, Kapingu MC, Wang MS, Chiou GC. Facilitation of retinal function recovery by coumarin derivatives. $J$ Ocul Pharmacol Ther 1997; 13(1): 69-79.

28. Song $B$, Zhenning $W$, Yan L, Sisi $X$, Guoren $H$, Ying $X$, Shuang $Z$, Linli $X$, Xuming $\quad D$, Shuang $G$. Immunosuppressive Activity of Daphnetin, One of Coumarin Derivatives, Is Mediated through Suppression of NF-KB and NFAT Signaling Pathways in Mouse T Cells. PloS one 2014; 9(5): e96502.

29. Manojlović N, Sovrlić M, Mašković $P$, Vasiljević $P$, Jušković $M$. Phenolic and flavonoid content and antioxidant activity of Daphne blagayana growing in Serbia. Serbian Journal of Experimental and Clinical Research 2014; 15(1): 21-27.

30. Cottigli F, Loy G, Garau D, Floris C, Caus M, Pompei R, Bonsignore $L$. Antimicrobial evaluation of coumarins and flavonoids from the stems of Daphne gnidium $L$. Phytomedicine 2001; 8(4): 302-305.

31. Sovrlić $M$, Vasiljević $P$, Jušković $M$, Mašković $P$, Manojlović N. Antimicrobial activity and HPLCanalysis of Daphne blagayana $L$. (THYMELAECEAE) extracts. Praxis Medica 2014; 43(4): 93-97. 